\title{
Sucrose-Induced Tolerance to and Recovery from Deicing Salt Damage in Containerized Ilex aquifolium L. and Quercus robur $\mathrm{L}$.
}

\author{
Sulaiman Al-Habsi and Glynn C. Percival
}

\begin{abstract}
Two outdoor experiments were conducted using containerized trees of the species holly (Ilex aquifolium L.) and English oak (Quercus robur L.) to determine the effectiveness and feasibility of sucrose to improve tolerance to and recovery from deicing salt (sodium chloride $[\mathrm{NaCl}]$ ) damage. In experiment one, sucrose plus a water-only control was applied as a root drench to containerized stock. Seventy-two hours later, $\mathrm{NaCl}$ was applied to both tree species as a root drench. At day 15 after $\mathrm{NaCl}$ application, effects on leaf chlorophyll a and b, carotenoid (lutein, $\beta$-carotene, neoxanthin, $\alpha$-carotene), xanthophyll (zeaxanthin, antheraxanthin, violaxanthin) concentration, leaf necrosis, and chlorophyll fluorescence $(\mathrm{Fv} / \mathrm{Fm})$ were measured. In experiment $2, \mathrm{NaCl}$ was applied as a root drench. At day 14 after $\mathrm{NaCl}$ application, plants were root drenched with sucrose plus a water-only control and recovery rates monitored by recording leaf necrosis, leaf chlorophyll concentration, and chlorophyll fluorescence over the proceeding 8 weeks. At week 8 after sucrose application, effects on tree growth were recorded. Sucrose was found to confer to both tree species a useful degree to tolerance to $\mathrm{NaCl}$ and improve recovery from salt-induced damage with promotion of photoxidative antioxidant pigments (carotenoids, xanthophylls) and chlorophylls strongly indicated as significantly contributing to the induction of $\mathrm{NaCl}$ tolerance.

Key Words. Carbohydrates; carbon compensation; carotenoids; chlorophyll fluorescence; holly; oak; photosynthetic chlorophylls; photosystem II; urban trees.
\end{abstract}

Deicing salts in the form of sodium chloride $(\mathrm{NaCl})$ can be a major chemical pollutant in urban landscapes resulting in substantial tree deaths (Hermans et al. 2003). Symptoms of excess salinity in trees include crown dieback, lesions on the stem or trunk, stomatal closure, and concomitant chlorophyll degradation resulting in leaves yellowing and development of leaf necrosis (Gibbs and Palmer 1994; Percival and Henderson 2002; Ryan 2005). In addition, symptoms can accumulate, e.g., tip burn of conifer, leading to necrosis of needles that can lead to dieback of limbs and tree death (Dobson 1991). Subzero temperatures experienced during the winter months are a frequent cause of deicing salt application to prevent the icing up of road networks. With increased traffic volume and road network expansion increasing the quantity of salt used for deicing operations, higher tree death rates are predicted (Percival and Henderson 2002).

Attempts to improve salt hardiness of urban trees, through plant breeding, are limited by the nature of salt tolerance, which is a quantitatively inherited trait controlled by many genes. Consequently, traditional breeding cycles requires many years to produce new cultivars with the desired saltresistant characteristics. Although perceived to be of benefit for major agricultural crops such as wheat or potato, such breeding programs are rare for urban trees. As a consequence, there is a demand for protectant compounds that are both inexpensive and can be applied at relatively short notice to increase the salt tolerance of plants.

A number of studies on the involvement of sugars in the response of plants to environmental and chemical stresses have reported protective effects on the leaf photosynthetic apparatus (Sulmon et al. 2004). The positive effect of sugars on reducing environmental stress in rice has been related to modifications and protection of photosystem II (Garg et al. 2002). In addition, enhancement of sugar levels in leaf chloroplasts has been shown to result in the protection of photosystem II to salt stress (Fukushima et al. 2001). Sucrose has also been shown to be involved in the thermostability of plant proteins after heat damage and maintaining chlorophyll levels and photosynthetic oxygen evolution after herbicide application (Robertson et al. 1994). Sugar alcohols have been shown to possess osmoprotectant functions that can help protect plants against salt and photoxidative stress caused by high light intensities (Williamson et al. 2002). Recent work has also shown that application of sugars confer a high degree of 
tolerance to the electron transport inhibiting herbicide atrazine in seedling material by maintaining high levels of leaf chlorophylls, photoxidative protecting carotenoid pigments, and photosynthetic efficiency (Sulmon et al. 2004). Work by Vartapetian (1993) demonstrated a positive effect of supplementing sugars for the survival of plants under anaerobic conditions. Protection of the leaf photosynthetic system has been shown to be important for the survival of plants under harsh environmental conditions. If the leaf photosynthetic apparatus remains unimpaired, then plants are able to produce the essential carbohydrates required for growth and repair of damaged tissue after the cessation of stress. If the leaf photosynthetic system is badly damaged, then the carbohydrates required for repair cannot be synthesized (Levitt 1980; Kitao et al. 1998; Arntz et al. 2000).

These studies raise the possibility that the salt tolerance of trees may be enhanced by applying sugars at or around the root zone potentially offering a simple system of reducing salt-induced tree losses in urban landscapes. Such research also has a number of practical advantages to professionals involved in urban tree management because sugars are watersoluble, nontoxic, environmentally safe, and inexpensive to purchase.

As a prerequisite to larger tree studies, the objectives of this investigation, using small containerized trees, were to determine the effectiveness and feasibility of sugar (sucrose) to improve tolerance to and recovery from deicing salt $(\mathrm{NaCl})$ damage.

\section{MATERIALS AND METHODS}

The experiment used 4 year old cell grown stock of Quercus robur L. (English oak) and Ilex aquifolium L. (holly) obtained from a commercial supplier. Six months before experiments (early November 2002), trees were potted into $4.5 \mathrm{~L}$ (1.17 gal) plastic pots filled with sterilized, i.e., heat and pressuretreated $\left(1 \mathrm{hr}\right.$ at $121^{\circ} \mathrm{C}\left[249.8^{\circ} \mathrm{F}\right]$ and $\left.0.103 \mathrm{MPa}\right)$ growing medium (loamy texture, $26 \%$ clay, $44 \%$ silt, $30 \%$ sand, $\mathrm{pH}$ 6.5) supplemented with the controlled-release nitrogen-based fertilizer Bartlett BOOST (N:P:K = 24:7:7; The Doggett Corporation, Lebanon, NJ) at a rate of $1 \mathrm{~g} / \mathrm{kg}$ compost. After potting, trees remained outdoors on a free-draining gravel surface subject to natural environmental conditions and watered as required. In early April, trees were moved to a polythene tunnel to protect against possible spring frosts and placed outdoors once the possibility of frosts had passed (30 April 2003). Sugar and salt treatments began in late May when both species were in full leaf. All physiological measurements taken throughout this investigation were made on leaf material present on the plant at the initiation of the experiment (existing leaves). Leaves were also tagged to ensure only the same leaf was measured repeatedly. Although new leaf formation was observed in both species between weeks 6 and 7 (experiment 2), no measurements of newly formed leaf tissue were made. Weeds were chemically controlled on the gravel surface using glyphosate before planting and by hand during the trial.

\section{Experiment 1: Prevention of Salt-Induced Damage by Prior Application of Sucrose}

Root drenches of sucrose, obtained from a local supermarket, at a concentration of either $25 \mathrm{~g}(0.9 \mathrm{oz})$ or $50 \mathrm{~g}(1.8 \mathrm{oz})$ sugar per liter of water were applied. Each tree received $0.5 \mathrm{~L}(0.13$ gal) of sugar solution, a volume deemed sufficient to fully saturate the soil as solution was observed emerging from drainage holes. Seventy-two hours after sugar application, root drenches $(0.5 \mathrm{~L}$ [0.13 gal] per pot) of $\mathrm{NaCl}$ were applied at a concentration of either $30 \mathrm{~g}(1.1 \mathrm{oz})$ or $60 \mathrm{~g}(2.1 \mathrm{oz}) \mathrm{NaCl}$ per liter of water. Containerized trees were left outdoors until day 15. During this period, no watering or fertilizers were applied. At day 15, a range of physiological measurements were made on leaf tissue as measures of tree vitality.

\section{Experiment 2: Effects of Sucrose on Recovery From Salt Damage}

Half-liter root drenches of $\mathrm{NaCl}(30 \mathrm{~g}$ [1.1 oz] or $60 \mathrm{~g}$ [2.1 oz] $\mathrm{NaCl}$ per liter of water) were applied to each containerized tree. Trees remained outdoors until day 14 when symptoms of $\mathrm{NaCl}$ toxicity could be visibly observed (leaves yellowing, marginal necrosis, wilting). At this stage, a number of physiological measurements were made on leaf tissue as measures of tree vitality. Immediately after measurements, $0.5 \mathrm{~L}(0.13$ gal) root drenches of sucrose at a concentration of either $25 \mathrm{~g}$ $(0.9 \mathrm{oz})$ or $50 \mathrm{~g}(1.8 \mathrm{oz})$ sugar per liter of water were applied. Sucrose treatments were reapplied at weeks 2, 4, and 6 after $\mathrm{NaCl}$ application. At weeks 1, 3, 5, and 7 after $\mathrm{NaCl}$ treatment, trees were watered as required.

\section{Experimental Design}

The experimental design used was a completely randomized block design (CRBD) in which pots were rerandomized on a weekly basis. Six trees per treatment were used at $1 \mathrm{~m}(3.3 \mathrm{ft})$ spacings to prevent competition for light.

\section{Physiological Measurements}

Leaves were adapted to darkness for $30 \mathrm{~min}$ by attaching light exclusion clips to the leaf surface and chlorophyll fluorescence was measured using a HandyPEA portable fluorescence spectrometer (Hansatech Instruments Ltd., King's Lynn, U.K.). Measurements were recorded up to $1 \mathrm{sec}$ with a data acquisition rate of $10 \mu \mathrm{s}$ for the first $2 \mathrm{~ms}$ and of $1 \mathrm{~ms}$ thereafter. The fluorescence responses were induced by a red (peak at $650 \mathrm{~nm}$ ) light of $1,500 \mu \mathrm{mol} \mathrm{m}^{-2} \mathrm{~s}^{-1}$ photosynthetically active radiation (PAR) intensity provided by an array of six light-emitting diodes. A performance index (PI) based on an equation that combines the relationship of calculated rela- 
tive number of reaction centers (RC) per energy absorbed (ABS) and then multiplied by two expressions describing the yields of light trapping ( $\phi$ po) and subsequent electron transport $\left(\Psi_{0}\right)$, i.e., $\mathrm{RC} / \mathrm{ABS} \times \phi \mathrm{po} /(1-\phi \mathrm{po}) \times \Psi_{0} /\left(1-\Psi_{0}\right.$; Clark et al. 1998, 2000; Percival and Fraser 2001) were used to quantify any effects on leaf tissue. PI values have been shown to be a highly sensitive measure of leaf photosynthetic activities as an indirect measure of plant vitality. PI values were automatically calculated by the HandyPEA.

For experiment 1 , leaf chlorophylls a and $\mathrm{b}$ and carotenoids (lutein, $\beta$-carotene, neoxanthin, $\alpha$-carotene, zeaxanthin, antheraxanthin, violaxanthin) were analyzed using a highperformance liquid chromatography (HPLC) system (Schindler and Lichtenthaler 1994). Leaf samples were excised from trees and immediately placed in liquid nitrogen. Thirty leaf samples per treatment, i.e., five leaves per tree, were taken. Pigment analysis was performed on the next day. Pigments were extracted from leaves with $100 \%$ aqueous acetone (quartz sand mortar) and separated and quantitatively determined by reverse phase HPLC applying a Nucleosil $\mathrm{C}_{18}$ column (particle size $4 \mu \mathrm{m}$ ). The solvent systems for the combined isocratic and gradient separation and quantification were acetonitrile-methanol-0.2 M tris/HCL buffer and methanol-hexane (Lichtenthaler et al. 1992).

For experiment 2, for comparative reasons and fast throughput of samples, chlorophyll a and b were extracted from leaf samples by suspending $1 \mathrm{~g}(0.035 \mathrm{oz})$ of fresh tissue in $5 \mathrm{~mL}(0.15 \mathrm{fl} \mathrm{oz}) 80 \% \mathrm{v} / \mathrm{v}$ aqueous acetone. After centrifugation in closed vials, an aliquot of the supernatant was transferred to a $1 \mathrm{~cm}(0.4 \mathrm{in})$ path glass cuvette and chlorophylls a and b calculated according to the equations of Lichtenthaler and Wellburn (1983) following measurement of absorbance at 663 and $645 \mathrm{~nm}$ in a spectrophotometer (PU8800 Pye Unicam).

Leaf necrosis was assessed visually. Each tree was rated on a 0 to 5 rating scale using a visual indexing technique and ratings on the scale: $0=$ no necrosis observed; $1=$ less than $5 \%$ of leaves affected and no aesthetic impact; $2=5 \%$ to $20 \%$ of leaves affected with some yellowing but little or no defoliation; $3=21 \%$ to $50 \%$ of leaves affected, significant defoliation, and/or leaf yellowing; $4=51 \%$ to $80 \%$ of leaves affected, severe foliar discoloration; and $5=81 \%$ to $100 \%$ of foliage affected with $90 \%$ to $100 \%$ defoliation.

At the conclusion of experiment 2 (week 8), trees were destructively harvested and leaf, shoot, and root dry weight recorded after oven drying at $85^{\circ} \mathrm{C}\left(185^{\circ} \mathrm{F}\right)$ for $48 \mathrm{hr}$. Leaf areas were quantified using a Delta-T area meter.

The results from the experiment were statistically analyzed using Genstat 5; significant differences from controls (nonsugar-treated trees) at the 95\% confidence level $(P>0.05)$, were tested for using analysis of variance (ANOVA) following checks for normality and equal variance distributions were met (Bartlett test). The comparisons of means of individual treatments were made by calculating $t$ values from the SED. Data for each tree species were analyzed separately. Recovery from salt-induced damage was quantified using correlation equations and coefficients of determination $\left(\mathrm{r}^{2}\right)$ calculated using the curve-fitting feature of SlideWrite using quadratic polynomial regression analysis.

\section{RESULTS}

\section{Experiment 1: Prevention of Salt-Induced Damage by Prior Application of Sucrose}

At day 15 after salt application, leaf chlorophyll fluorescence PI and total chlorophyll values were between $38 \%$ and $58 \%$ higher in English oak and 33\% to 57\% and 14\% to $27 \%$ higher in holly, respectively, pretreated with sucrose at 30 and $60 \mathrm{~g}$ (1.1 and $2.1 \mathrm{oz}$ ) (Tables 1 and 2). Likewise, leaf necrosis was reduced by $33 \%$ to $57 \%$ in English oak and by $30 \%$ to $68 \%$ in holly when trees were pretreated with sugars (30 and $60 \mathrm{~g}$ [1.1 and $2.1 \mathrm{oz}]$ ), compared to trees treated with salt only, at 30 and $60 \mathrm{~g}$ (1.1 and $2.1 \mathrm{oz})$ per liter of water (Tables 1 and 2). Such responses in sugar-treated trees indicate less impairment of the leaf photosynthetic integrity, improved photosynthetic efficiency, and reduced degradation of the chlorophyll molecule structure compared with watertreated controls. No marked differences were recorded between species in response to salt treatment only with similar PI (2.17 to 4.45) and leaf necrosis (3.4 to 4.2) values recorded (Tables 1 and 2) at day 15 after treatment. Leaf carotenoid (lutein, $\beta$-carotene, neoxanthin, $\alpha$-carotene) and xanthophylls (zeaxanthin, antheraxanthin, and violaxanthin) were $\approx 30 \%$ to $60 \%$ higher in sucrose-treated trees compared with no sucrose-treated trees irrespective of species at the cessation of experiment 1 (day 15). Maximal increases in total carotenoids (carotenoid + xanthophylls) were found in trees after application of sucrose at $25 \mathrm{~g}(0.9 \mathrm{oz})$ per liter of water followed by $30 \mathrm{~g}(1.1 \mathrm{oz}) \mathrm{NaCl}$ at day 3 after sucrose treatment. None of the treatments used in this investigation altered the ratio of chlorophyll a:b in English oak (2.99 to 3.21) or holly (3.22 to 3.45; Tables 1 and 2). Irrespective of species, there were no significant differences in leaf area, root, shoot, leaf, or total plant dry weight at day 15 after treatment (data not shown).

\section{Experiment 2: Effects of Sucrose on Recovery From Salt Damage}

The pattern of recovery 2 weeks after salt application in PI, leaf chlorosis, and chlorophyll content is shown for English oak and holly (Tables 3 and 4). At 2 weeks after salt treatment, all three parameters began to recover irrespective of treatment (with or without sucrose). Consequently, the pattern of recovery was quantified by quadratic regression analysis to compare the rate of recovery from week 2 until the cessation 

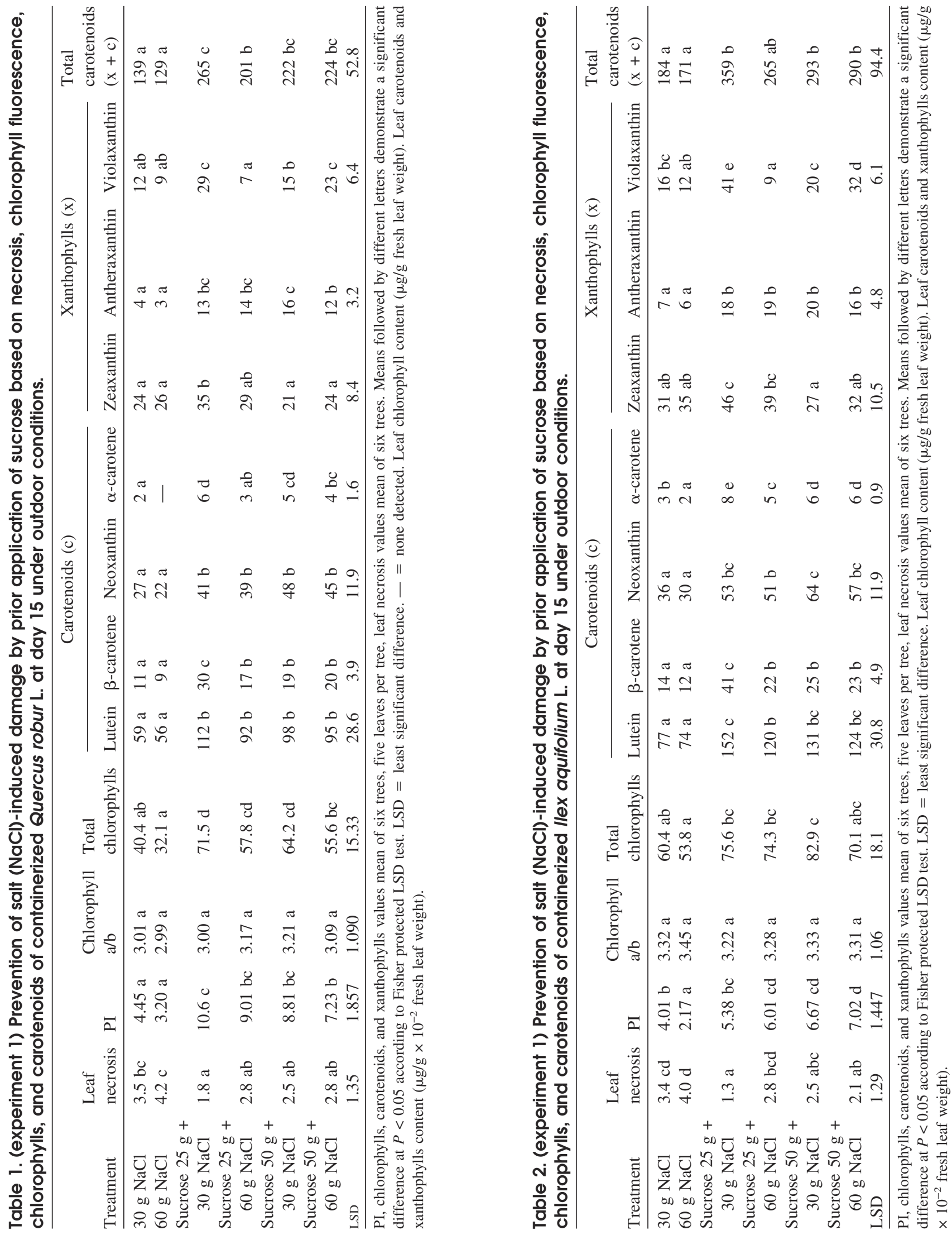
Table 3. (experiment 2) Sucrose-enhanced recovery of leaf PI, necrosis, and chlorophyll content of containerized English oak (Quercus robur L.) placed outdoors with time (weeks) based on quadratic regression analysis after application of salt ( $\mathrm{NaCl})$.

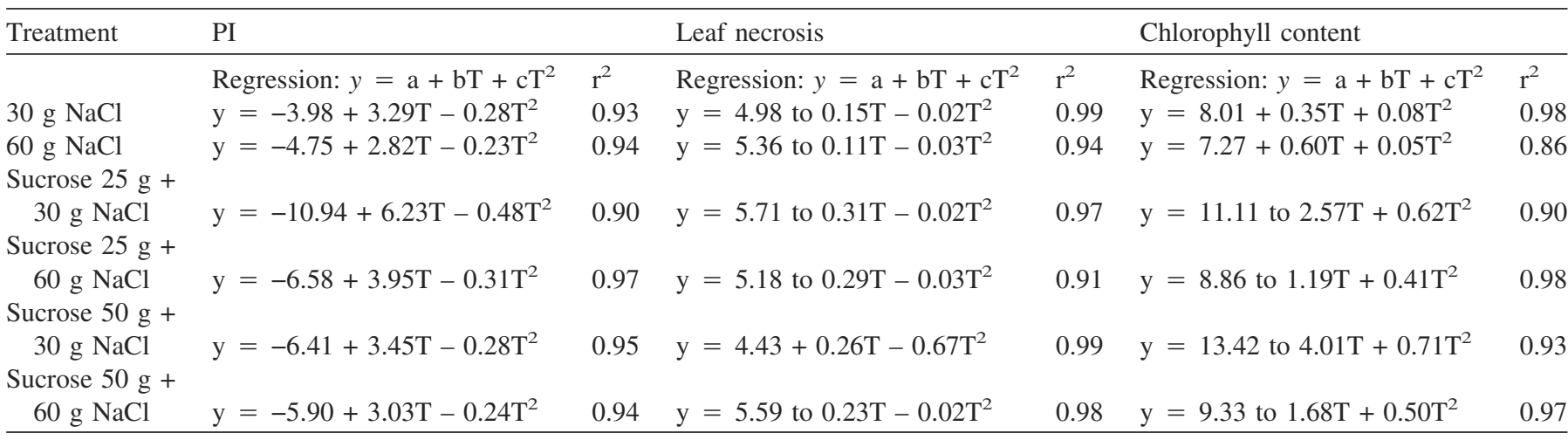

$\mathrm{y}$, leaf PI, necrosis, and chlorophyll content value; a, leaf PI, necrosis and chlorophyll content of control value (calculated intercept); b, rate of PI, necrosis, and chlorophyll content with time $(\mathrm{T}), \mathrm{c},=$ rate of change. PI and chlorophyll values mean of six trees, five leaves per tree, leaf necrosis values mean of six trees.

of the experiment at week 8 (Tables 3 and 4). Irrespective of species, sucrose-treated trees were the most capable of recovery as reflected by higher regression values with respect to PI and leaf chlorophyll recovery and lower regression values with respect to leaf necrosis (Tables 3 and 4). Such responses in sucrose-treated trees are associated with enhanced recovery of leaf photosynthetic integrity, improved photosynthetic efficiency, and reduced degradation of the chlorophyll molecule structure compared with nonsucrose-treated trees. Recovery rates of salt-damaged trees treated with sucrose ranged from 5\% to 50\% higher than nonsucrose-treated trees (Tables 3 and 4). In all cases, nonsucrose-treated trees had the least capacity for recovery. Regardless of tree species, maximal recovery rates were recorded in trees treated with sucrose at $25 \mathrm{~g}(0.9 \mathrm{oz})$ rather than $50 \mathrm{~g}(1.8 \mathrm{oz})$ after salt treatment

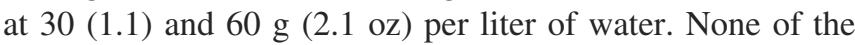

treatments used in this investigation altered the ratio of chlorophyll a:b in English oak (3.09 to 3.24) or holly (3.29 to 3.44; data not shown). Eight weeks after sucrose application, leaf area, root, leaf, shoot, and total plant dry weight were consistently higher (20\% to $50 \%)$ in sucrose-treated trees irrespective of species with one exception: English oak treated with $50 \mathrm{~g}(1.8 \mathrm{oz})$ sucrose after application of salt at $60 \mathrm{~g}(2.1 \mathrm{oz})$ per liter of water in which values were comparable with salt-only-treated English oak (Tables 5 and 6). Regardless of tree species, maximal growth responses were recorded in trees treated with sucrose at $25 \mathrm{~g}(0.9)$ rather than $50 \mathrm{~g}(1.8 \mathrm{oz})$ after salt treatments (Tables 5 and 6).

\section{DISCUSSION}

There is a growing body of evidence that application of carbohydrates, particularly sucrose, can provide useful protec-

Table 4. (experiment 2) Sucrose-enhanced recovery of leaf PI, necrosis, and chlorophyll content of containerized holly (llex aquifolium L.) placed outdoors with time (weeks) based on quadratic regression analysis after application of salt $(\mathrm{NaCl})$.

\begin{tabular}{|c|c|c|c|c|c|c|}
\hline Treatment & PI & & Leaf necrosis & & Chlorophyll Content & \\
\hline & Regression: $y=\mathrm{a}+\mathrm{bT}+\mathrm{cT}^{2}$ & $r^{2}$ & Regression: $y=\mathrm{a}+\mathrm{bT}+\mathrm{cT}^{2}$ & $r^{2}$ & Regression: $y=\mathrm{a}+\mathrm{bT}+\mathrm{cT}^{2}$ & $r^{2}$ \\
\hline $30 \mathrm{~g} \mathrm{NaCl}$ & $\mathrm{y}=1.98+1.30 \mathrm{~T}-0.18 \mathrm{~T}^{2}$ & 0.42 & $\mathrm{y}=4.50$ to $0.11 \mathrm{~T}-0.01 \mathrm{~T}^{2}$ & 0.95 & $\mathrm{y}=-2.51+8.82 \mathrm{~T}-0.53 \mathrm{~T}^{2}$ & 0.93 \\
\hline $60 \mathrm{~g} \mathrm{NaCl}$ & $\mathrm{y}=2.39+0.96 \mathrm{~T}-0.10 \mathrm{~T}^{2}$ & 0.84 & $\mathrm{y}=4.56$ to $0.12 \mathrm{~T}-0.02 \mathrm{~T}^{2}$ & 0.98 & $\mathrm{y}=-4.10+8.60 \mathrm{~T}-0.40 \mathrm{~T}^{2}$ & 0.88 \\
\hline Sucrose $25 \mathrm{~g}+$ & & & & & & \\
\hline $\begin{array}{c}30 \mathrm{~g} \mathrm{NaCl} \\
\text { Sucrose } 25 \mathrm{~g}+\end{array}$ & $y=-2.36+3.73 \mathrm{~T}-0.32 \mathrm{~T}^{2}$ & 0.91 & $\mathrm{y}=4.36$ to $0.16 \mathrm{~T}-0.01 \mathrm{~T}^{2}$ & 0.94 & $y=-15.15+16.75 \mathrm{~T}-1.08 \mathrm{~T}^{2}$ & 0.94 \\
\hline $60 \mathrm{~g} \mathrm{NaCl}$ & $\mathrm{y}=0.315+2.05 \mathrm{~T}-0.19 \mathrm{~T}^{2}$ & 0.90 & $\mathrm{y}=4.20$ to $0.03 \mathrm{~T}-0.02 \mathrm{~T}^{2}$ & 0.95 & $\mathrm{y}=4.70$ to $3.91 \mathrm{~T}+0.15 \mathrm{~T}^{2}$ & 0.96 \\
\hline $\begin{array}{l}\text { Sucrose } 50 \mathrm{~g}+ \\
\quad 30 \mathrm{~g} \mathrm{NaCl}\end{array}$ & $\mathrm{y}=1.45+1.41 \mathrm{~T}-0.12 \mathrm{~T}^{2}$ & 0.88 & $\mathrm{y}=3.37+0.09 \mathrm{~T}-0.03 \mathrm{~T}^{2}$ & 0.96 & $\mathrm{y}=-9.96+13.49 \mathrm{~T}-0.81 \mathrm{~T}^{2}$ & 0.90 \\
\hline $\begin{array}{l}\text { Sucrose } 50 \mathrm{~g}+ \\
\quad 60 \mathrm{~g} \mathrm{NaCl}\end{array}$ & $\mathrm{y}=0.89+1.90 \mathrm{~T}-0.17 \mathrm{~T}^{2}$ & 0.96 & $\mathrm{y}=4.24$ to $0.10 \mathrm{~T}-0.02 \mathrm{~T}^{2}$ & 0.98 & $\mathrm{y}=-7.40+11.67 \mathrm{~T}-0.66 \mathrm{~T}^{2}$ & 0.88 \\
\hline
\end{tabular}

$\mathrm{y}$, leaf PI, necrosis, and chlorophyll content value; a, leaf PI, necrosis and chlorophyll content of control value (calculated intercept); b, rate of PI, necrosis, and chlorophyll content with time $(\mathrm{T}), \mathrm{c},=$ rate of change. PI and chlorophyll values mean of six trees, five leaves per tree, leaf necrosis values mean of six trees. 
Table 5. (experiment 2) The influence of sucrose on growth of containerized English oak (Quercus robur L.) placed outdoors at week 8 after application of salt ( $\mathrm{NaCl})$.

\begin{tabular}{|c|c|c|c|c|c|}
\hline Treatment & $\begin{array}{l}\text { Leaf area } \\
\left(\mathrm{cm}^{2}\right)\end{array}$ & $\begin{array}{l}\text { Root DW } \\
(\mathrm{g})\end{array}$ & $\begin{array}{l}\text { Shoot DW } \\
(\mathrm{g})\end{array}$ & $\begin{array}{l}\text { Leaf DW } \\
(\mathrm{g})\end{array}$ & $\begin{array}{l}\text { Total DW } \\
(\mathrm{g})\end{array}$ \\
\hline $30 \mathrm{~g} \mathrm{NaCl}$ & $516 \mathrm{ab}$ & $8.97 \mathrm{ab}$ & $7.91 \mathrm{ab}$ & $3.56 \mathrm{~b}$ & $20.44 \mathrm{ab}$ \\
\hline $60 \mathrm{~g} \mathrm{NaCl}$ & $401 \mathrm{a}$ & $7.37 \mathrm{a}$ & $9.61 \mathrm{ab}$ & $1.97 \mathrm{a}$ & $18.95 \mathrm{a}$ \\
\hline Sucrose $25 \mathrm{~g}+30 \mathrm{~g} \mathrm{NaCl}$ & $604 \mathrm{bc}$ & $11.33 \mathrm{~cd}$ & $12.69 \mathrm{c}$ & $4.31 \mathrm{bc}$ & $28.33 \mathrm{c}$ \\
\hline Sucrose $25 \mathrm{~g}+60 \mathrm{~g} \mathrm{NaCl}$ & $701 \mathrm{c}$ & $12.46 \mathrm{~d}$ & $12.86 \mathrm{c}$ & $4.82 \mathrm{c}$ & $30.14 \mathrm{c}$ \\
\hline Sucrose $50 \mathrm{~g}+30 \mathrm{~g} \mathrm{NaCl}$ & $703 \mathrm{c}$ & $10.07 \mathrm{bc}$ & $10.38 \mathrm{bc}$ & $4.46 \mathrm{bc}$ & $24.91 \mathrm{bc}$ \\
\hline Sucrose $50 \mathrm{~g}+60 \mathrm{~g} \mathrm{NaCl}$ & $555 \mathrm{abc}$ & $8.71 \mathrm{ab}$ & $7.72 \mathrm{a}$ & $3.88 \mathrm{bc}$ & $20.31 \mathrm{c}$ \\
\hline LSD & 159.9 & 2.005 & 2.650 & 1.005 & 5.265 \\
\hline
\end{tabular}

All values mean of six trees. Means followed by different letters demonstrate a significant difference at $P<0.05$ according to Fisher protected LSD test. LSD $=$ least significant difference.

tive properties to plants against a diverse array of abiotic and chemical stresses. Work by Sulmon et al. (2004) demonstrated exogenous application of sucrose and, to a lesser extent, glucose were found to confer to Arabidopsis seedlings a high level of tolerance to the plastoquinone B binding herbicide atrazine through maintenance of chlorophylls, carotenoids, and protection of photosystem II. Moreover, atrazine in the presence of sucrose was found to have a paradoxically positive effect of seedling development. Atrazine treatment alone arrested seedling development with cotyledon bleaching and seedling death. The importance of carbohydrates in waterlogging tolerance has been confirmed by experiments with supplying of exogenous sugar to hypoxic or anoxic root systems (Basra and Basra 1997). Glucose prolonged the retention of root elongation potential under anoxia (Waters et al. 1991) facilitating carbon reallocation from below-ground to above-ground components during waterlogging, an effective physiological survival strategy in decreasing the amount of respiring root tissue relative to volume and therefore the oxygen demand of the root system for aerobic respiration (Naidoo and Naidoo 1992). The addition of glucose to the rooting medium improved the anoxia tolerance of seedling material (VanToai et al. 1995). Adventitious roots of rice survived only $4 \mathrm{hr}$ of anoxia-induced stress that was extended to $44 \mathrm{hr}$ after the application of exogenous glucose (Webb and Armstrong 1983). Root ultrastructure injury under anoxia was prevented after supplying the roots with glucose, demonstrating that there is a positive effect of exogenously supplied sugar in the survival of plants under anaerobic conditions (Vartapetian 1993). In addition, sucrose-based enhancement of chlorophyll accumulation has been shown to be a useful component of drought tolerance in a range of plants (Basra and Basra 1997).

Besides carbon feeding of primary metabolism, sugars are also the precursors of antioxidant compounds, which may be efficient for protection against salt-mediated oxidative stress (Foyer et al. 1991). Although information regarding the role of photoxidative antioxidant leaf pigments in response to salt damage is limited, a positive role of carotenoids and xanthophylls is implicated. Buildup of high-energy reactive oxygen species (ROS) is a common response after salt-induced stress (Zhu 2001). In theory, prolonged stomatal closure caused by salt damage would lead to plant starvation and death as a result of the loss of fixed carbon. Although this effect would eventually occur, more rapid toxicity results from cessation of light energy into photochemical energy resulting in the production of high-energy ROS. Unchecked ROS can be converted into hydrogen peroxide (bleach), which diffuses over

Table 6. (experiment 2) The influence of sucrose on growth of containerized holly (llex aquifolium L.) placed outdoors at week 8 after application of salt $(\mathrm{NaCl})$.

\begin{tabular}{llllll}
\hline Treatment & $\begin{array}{l}\text { Leaf area } \\
\left(\mathrm{cm}^{2}\right)\end{array}$ & $\begin{array}{l}\text { Root DW } \\
(\mathrm{g})\end{array}$ & $\begin{array}{l}\text { Shoot DW } \\
(\mathrm{g})\end{array}$ & $\begin{array}{l}\text { Leaf DW } \\
(\mathrm{g})\end{array}$ & $\begin{array}{l}\text { Total DW } \\
(\mathrm{g})\end{array}$ \\
\hline $30 \mathrm{~g} \mathrm{NaCl}$ & $104 \mathrm{ab}$ & $1.51 \mathrm{a}$ & $2.66 \mathrm{ab}$ & $2.21 \mathrm{~b}$ & $6.38 \mathrm{ab}$ \\
$60 \mathrm{~g} \mathrm{NaCl}$ & $87 \mathrm{a}$ & $1.62 \mathrm{ab}$ & $2.55 \mathrm{a}$ & $1.54 \mathrm{a}$ & $5.71 \mathrm{a}$ \\
Sucrose $25 \mathrm{~g}+30 \mathrm{~g} \mathrm{NaCl}$ & $150 \mathrm{c}$ & $3.08 \mathrm{c}$ & $2.58 \mathrm{a}$ & $2.84 \mathrm{c}$ & $8.50 \mathrm{c}$ \\
Sucrose $25 \mathrm{~g}+60 \mathrm{~g} \mathrm{NaCl}$ & $153 \mathrm{~d}$ & $2.64 \mathrm{c}$ & $3.00 \mathrm{~b}$ & $3.32 \mathrm{c}$ & $8.96 \mathrm{c}$ \\
Sucrose $50 \mathrm{~g}+30 \mathrm{~g} \mathrm{NaCl}$ & $125 \mathrm{bc}$ & $2.70 \mathrm{c}$ & $2.79 \mathrm{ab}$ & $3.20 \mathrm{c}$ & $8.69 \mathrm{c}$ \\
Sucrose $50 \mathrm{~g}+60 \mathrm{~g} \mathrm{NaCl}$ & $119 \mathrm{abc}$ & $2.38 \mathrm{bc}$ & $2.67 \mathrm{ab}$ & $2.15 \mathrm{ab}$ & $7.20 \mathrm{~b}$ \\
LSD & 33.7 & 0.781 & 0.365 & 0.625 & 1.165 \\
\hline
\end{tabular}

All values mean of six trees. Means followed by different letters demonstrate a significant difference at $P<0.05$ according to Fisher protected LSD test. LSD $=$ least significant difference. 
much greater distances and causes further oxidative damage. Unless ROS are detoxified, there is irreversible damage to membrane lipids, proteins, and nucleic acids. Carotenoids (carotenes and xanthophylls) are found inside the chloroplasts where they function as accessory pigments to chlorophyll helping the plant harvest more light during photosynthesis. They also serve as photoxidative pigments (primarily antioxidants) by quenching and detoxifying ROS (Hasegawa et al. 2000; Apse and Blumwald 2002; Chinnusamy et al. 2004). In fact, available information strongly indicates that salt tolerance is linked to ROS scavenging and detoxification (Chinnusamy et al. 2004). In addition, sucrose and fructose have been shown to function directly to protect leaf cellular structure through scavenging ROS (Hasegawa et al. 2000; Zhu 2001). In experiment 1 , higher concentrations of all the major leaf photoxidative carotenoid and xanthophylls pigments were found in sucrose-treated compared to non-sucrosetreated plants at day 15 following the application of salt to tree root systems. In experiment 2, recovery rates of leaf chlorophyll were higher in sucrose-treated trees compared to non-sucrose-treated trees following salt-induced damage to leaf tissue. The combined effect of sucrose and salt on increased antioxidant pigment and chlorophyll levels may have significantly contributed to the induction of salt tolerance in both test species at day 15 after salt application (experiment 1) and greater recover rates from salt-induced leaf tissue damage (experiment 2). Other mechanisms, not explored in this study, by which sucrose may have induced stress resilience in both English oak and holly include compensation of photosynthetic impairment by direct carbon feeding, stabilization of protein structure, induction of defense-related genes, and alterations to root rhizosphere microbial populations (see Koch 1996; Fukushima et al. 2001; Sulmon et al. 2004; Percival and Fraser 2005 for further details.

Within the United Kingdom, deicing salts are directly responsible for the death of many roadside and city trees (Percival and Henderson 2002). Remedial measures after salt damage include dilution of the soil with excess water, application of calcium-based compounds, and/or installation of physical barriers around the tree (Ryan 2005). The practicalities of our results indicate that application of sugars to saltdamaged tress may provide an alternative remedial system to aid tree recovery. Importantly, sugars are inexpensive, nontoxic to humans, plants, and animals, and can easily be incorporated into existing management strategies for the aftercare of trees after planting out. In addition, results indicate a protective role of sugars against salt-induced stress. Further studies are ongoing evaluating the protective properties of carbohydrates in trees against a range of environmental stresses frequently encountered in urban landscapes using larger landscape-sized planting material $>50 \mathrm{~mm}$ ( 2 in) in diameter.
Acknowledgment. The authors are grateful for funding in part from the TREE Fund (Hyland Johns Grant).

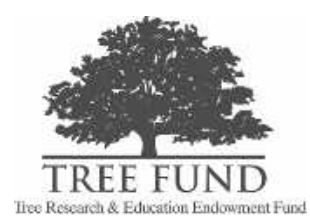

\section{LITERATURE CITED}

Apse, M.P., and E. Blumwald. 2002. Engineering salt tolerance in plants. Current Opinion in Biotechnology 13: 146-150.

Arntz, A.M., E.H. Delucia, and N. Jordan. 2000. From fluorescence to fitness: Variation in photosynthetic rate affects fecundity and survivorship. Ecology 81:2567-2576.

Basra, A.S., and R.K. Basra. 1997. Mechanisms of environmental stress resistance in plants. Publ. Harwood Academic Publishers, UK. 71 pp.

Chinnusamy, V., K. Schumaker, and J.K. Zhu. 2004. Molecular genetic perspectives on cross-talk and specificity in abiotic stress signalling in plants. Journal of Experimental Botany 55:225-236.

Clark, A.J., W. Landolt, J. Bucher, and R.J. Strasser. 1998. The response of Fagus sylvatica to elevated $\mathrm{CO}_{2}$ and ozone probed by the JIP-test based on the chlorophyll fluorescence rise: OJIP, pp. 283-286. In Responses of Plant Metabolism to Air Pollution and Global Change. De Kok J.L., and Stulen, I., Eds. Brackhuys Publishers, Leiden, The Netherlands.

. 2000. Beech (Fagus sylvatica L.) response to ozone exposure assessed with a chlorophyll a fluorescence performance index. Environmental Pollution (Barking, Essex: 1987) 109:501-507.

Dobson, M.C. 1991. De-icing salt damage to trees and shrubs. Forestry Commission Bulletin 101.

Foyer, C., M. Lelandais, C. Galap, and K. Kunert. 1991. Effects of elevated cytosolic glutathione reductase activity on cellular glutathione pool and photosynthesis in leaves under normal and stress conditions. Plant Physiology 97: 863-872.

Fukushima, E., Y. Arata, T. Endo, U. Sonnewald, and F. Sato. 2001. Improved salt tolerance in transgenic tobacco expressing apoplastic yeast derived invertase. Plant \& Cell Physiology 42:245-249.

Garg, A.K., J.K. Kim, T.G. Owens, A.P. Ranwala, Y. Do Choi, L.V. Kochian, and R.J. Wu. 2002. Trehalose accumulation in rice plants confers high tolerance levels to different abiotic stresses. Proceedings of the National Academy of Sciences of the United States of America 99:15898-15903.

Gibbs, J.N., and C.A. Palmer. 1994. A survey of damage to roadside trees in London caused by the application of de-icing salt during the 1990/91 winter. Arboricultural Journal 18:321-343. 
Hasegawa, P.M., R.A. Bressan, J. Zhu, and H.J. Bohnert. 2000. Plant cellular and molecular responses to high salinity. Annual Review of Plant Physiology and Plant Molecular Biology 51:463-499.

Hermans, C., M. Smeyers, R. Maldonado, M. Eyletters, R.J. Strasser, and J.P. Delhayne. 2003. Quality assessment of urban trees. A comparative study of physiological characterisation, airborne imaging and on site fluorescence monitoring by the OJIP-test. Journal of Plant Physiology 160:81-90.

Kitao, M., T.T. Lei, and T. Koike. 1998. Application of chlorophyll fluorescence to evaluate Mn tolerance of deciduous broad-leaved tree seedlings native to northern Japan. Tree Physiology 18:135-140.

Koch, K. 1996. Carbohydrate modulated gene expression in plants. Annual Review of Plant Physiology 47:509-540.

Levitt, J. 1980. Responses of plants to environmental stress, Vol I. Academic Press, New York, NY. pp. 202-207.

Lichtenthaler, H.K., S. Burkart, C. Schindler, and F. Stober. 1992. Changes in photosynthetic pigments and in vivo chlorophyll fluorescence parameters under photoinhibitory growth conditions. Photosynthetica 27:343-353.

Lichtenthaler, H.K., and A.R. Wellburn. 1983. Determinations of total carotenoids and chlorophylls $\mathrm{a}$ and $\mathrm{b}$ of leaf extracts in different solvents. Biochemical Society Transactions 11:591-593.

Naidoo, L., and T. Naidoo. 1992. Waterlogging responses of Sporobolus virginicus (L.). Kunth. Oecologia 90: 445-450.

Percival, G.C., and G.A. Fraser. 2001. Measurement of the salinity and freezing tolerance of Crataegus genotypes using chlorophyll fluorescence. Journal of Arboriculture 27:233-245.

- 2005. Use of sugars to improve root growth and increase transplant success of Birch (Betula pendula Roth.). Journal of Arboriculture 31:66-78.

Percival, G.C., and A. Henderson. 2002. The influence of de-icing salts on growth and leaf photochemistry of seven urban tree species. Arboricultural Journal 26:23-43.

Robertson, A.J., M. Ishikawa, L.V. Gusta, and S.L. MacKenzie. 1994. Abscisic acid-induced heat tolerance in Bromus inermis cell-suspension cultures. Heat-stable abscisic acid-responsive polypeptides in combination with sucrose confer enhanced stability. Plant Physiology 105:181-190.

Ryan, J. 2005. Salt damage to trees. Essential ARB. 16: $11-12$.

Schindler, C., and H.K. Lichtenthaler. 1994. Is there a correlation between light-induced zeaxanthin accumulation and quenching of variable chlorophyll a fluorescence? Plant Physiology and Biochemistry 32:813-823.

Sulmon, C., G. Gouesbet, I. Couée, and A. El Amrani. 2004. Sugar-induced tolerance to atrazine in Arabidopsis seedlings: Interacting effects of atrazine and soluble sugars on
psbA mRNA and D1 protein levels. Plant Science 167: 913-923.

VanToai, T.T., P. Saglio, B. Richards, and A. Pradet. 1995. Developmental regulation of anoxia stress tolerance in maize. Plant, Cell \& Environment 18:937-942.

Vartapetian, B.B. 1993. Plant physiological responses to anoxia. International Crop Science Proceedings, 1:721-726. Madison, WI, Crop Science of America.

Waters, I., P.J.C. Kuiper, E. Watkin, and H. Greenway. 1991. Effects of anoxia on wheat seedlings. I. Interactions between anoxia and other environmental factors. Journal of Experimental Botany 42:1427-1435.

Webb, T., and W. Armstrong. 1983. The effects of anoxia and carbohydrates on the growth, vitality of rice, pea and pumpkin roots. Journal of Experimental Botany 34: 579-603.

Williamson, J.D., D.B. Jennings, W.W. Guo, D.M. Pharr, and M. Ehrenshaft. 2002. Sugar alcohols, salt stress and fungal resistance: Polyols-multifunctional plant protection. Journal of the American Society for Horticultural Science 127:467-473.

Zhu, J.K. 2001. Plant salt tolerance. Trends in Plant Science 6:66-71.

Sulaiman Al-Habsi

Research Assistant and MSc Candidate

R.A. Bartlett Tree Research Laboratory, Europe

The University of Reading

2 Early Gate, Whiteknights

Reading, RG6 6AU, United Kingdom

Glynn C. Percival (corresponding author)

Plant Physiologist/Technical Support Specialist

R.A. Bartlett Tree Research Laboratory, Europe

The University of Reading

2 Early Gate, Whiteknights

Reading, RG6 6AU, United Kingdom

gpercival@bartlettuk.com

Résumé. Deux expériences sur le terrain ont été menées au moyen de houx (Ilex aquifolium L.) et de chêne anglais (Quercus robur L.) en contenant afin de déterminer l'efficacité et la faisabilité du saccharose pour améliorer la tolérance et la reprise suite à des dommages par le sel de déglaçage (chlorure de sodium ou $\mathrm{NaCl}$ ). Dans l'expérience no 1, du saccharose ou de l'eau simplement dans le cas du groupe-témoin ont été appliqué par trempage des racines sur les végétaux en contenant. Soixante-douze heures plus tard, le $\mathrm{NaCl}$ a été appliqué sur les deux espèces par trempage des racines. Au jour 15 suivant l'application du $\mathrm{NaCl}$, les effets sur les concentrations en chlorophylle foliaire a et $\mathrm{b}$, en caroténoïdes (lutéine, $\beta$-carotène, néoxanthine, $\alpha$-carotène) et en xantophylles (zéaxanthine, anthéraxanthine, violaxanthine) ainsi que la nécrose foliaire et 
la fluorescence de la chlorophylle (Fv/Fm) ont été mesurés. Dans l'expérience no 2, deux applications de $\mathrm{NaCl}$ ont été faites par trempage des racines. Au jour 14 suivant l'application du $\mathrm{NaCl}$, les plantes ont été trempées avec du saccharose ou encore simplement au moyen d'eau pour le groupe-témoin; par la suite, le taux de recouvrement a été mesuré durant les huit semaines suivantes en enregistrant des données sur la nécrose foliaire, la concentration en chlorophylle et la fluorescence de la chlorophylle. À la semaine 8, les effets de l'application de saccharose ont été enregistrés par rapport au taux de croissance. Le saccharose s'est avéré efficace pour fournir aux deux espèces un degré utile de tolérance au $\mathrm{NaCl}$ et pour améliorer la capacité de reprise suite aux dommages induits par le sel, et ce en favorisant les pigments photos oxidants anti-oxidants (caroténoïdes, xantophylles) et la chlorophylle qui ont contribués significativement à l'induction de la tolérance au $\mathrm{NaCl}$.

Zusammenfassung. Um die Effektivität und Einsatzmöglichkeit von Sukrose zur Verbesserung von und Erholung von Salzschäden zu bestimmen, wurden zwei Freilandexperimente mit den getopften Stechpalmen und Eichen durchgeführt. Im ersten Experiment wurde Sukrose und Wasser nur zur Kontrolle auf die getopften Pflanzen gegossen. 70 Stunden später wurde auf gleiche Weise $\mathrm{NaCl}$ appliziert. Am 15. Tag nach der Salzapplikation wurden Effekte an Blattchlorophyll a und b, Carotenoiden, Xanthophyll-Konzentration, Blattnekrosen und Chlorophyll-Fluoreszenz gemessen. Im zweiten Experiment wurde $\mathrm{NaCl}$ im Gießwasser appliziert. Am 14 tag nach der Salzzufuhr wurden die Wurzeln in umgekehrter Weise mit Sukrose und nur Wasser gegossen und die Erholungsraten bezüglich Blattnekrosen, Blattchlorophyll-Konzentration und ChlorophyllFluoreszenz über den Zeitraum von 8 Wochen aufgezeichnet. In der
8. Woche nach der Zuckerapplikation wurden die Auswirkungen auf das Wachstum aufgezeichnet. Zucker kann bei beiden Baumarten zu einer sinnvollen $\mathrm{NaCl}$-Toleranz führen und verbessert die Erholung von Salzschäden durch eine Promotion der Photooxidantien (Karotinoide, Xanthophyll) und des Chlorophylls, was auf eine deutliche Beteiligung an der NaCl-Toleranz schließen lässt.

Resumen. Se condujeron dos experimentos en los exteriores usando árboles containerizados de las especies de acebo (Ilex aquifolium L.) y encino inglés (Quercus robur L.) para determinar la efectividad y factibilidad de la sucrosa para mejorar la tolerancia y recobrarse del daño de las sales descongelantes (cloruro de sodio; $\mathrm{NaCl}$ ). En el experimento uno, el control fue sucrosa más agua solamente, aplicada a las dos especies de árboles en un zanja en la raíz. El día 15 posterior a la aplicación de $\mathrm{NaCl}$ se midieron los efectos de clorofila a y b de la hoja, carotenoide (luteína, $\beta$-caroteno, neoxanthina $\alpha$-caroteno), concentraciones de xanthophylla (zeaxanthina, antheraxanthina, violaxanthina), necrosis de la hoja y fluorescencia de la clorofila (Fv/Fm). En el experimento dos, el $\mathrm{NaCl}$ fue aplicado en la raíz. El día 14 posterior a la aplicación de $\mathrm{NaCl}$ se aplicó sucrosa más agua en la zanja en la raíz y se monitorearon las tasas de recobramiento por el registro de la necrosis de la hoja, concentración y fluorescencia de clorofila en las siguientes ocho semanas. En la semana 8 post aplicación de la sucrosa, se registraron los efectos en el crecimiento del árbol. Se encontró que la sucrosa confiere a ambas especies un grado útil de tolerancia a $\mathrm{NaCl}$ y mejora el recobramiento del daño inducido por sal con promoción de pigmentos foto-oxidativos antioxidantes (carotenoides, xanyhopyillas) y clorofilas; indicada fuertemente como una contribución significativa a la inducción de tolerancia al $\mathrm{NaCl}$. 